\title{
Durability of Lightweight Concrete with Expanded Glass and Silica Fume
}

\author{
by Maddalena Carsana and Luca Bertolini
}

\begin{abstract}
Although concrete has a significant environmental impact, it also offers interesting opportunities of recycling waste materials that may improve its sustainability. Together with different other industrial residues that are normally recycled in concrete, expanded glass can be used as a lightweight aggregate. However, the use of glass in concrete raises concerns about durability because of its poor stability in alkaline environments. This paper presents a study aimed at investigating the durability of lightweight concrete (LWC) made with expanded glass and silica fume used, respectively, for the replacement of the fine fraction of aggregate and as mineral addition. Expanded glass particles were characterized in terms of alkali-aggregate reaction, density, absorption, and microstructure. The combination of expanded glass and silica fume led to a structural lightweight concrete that was able to maintain its strength under exposure to moist and hot conditions and showed high resistance to the penetration of aggressive agents.
\end{abstract}

Keywords: alkali-silica reaction; chlorides; durability; expanded glass; silica fume; sulfates.

\section{INTRODUCTION}

Sustainability requirements require that the design of buildings and infrastructures not only focuses on optimization of the strength and durability performance, but takes into account environmental costs. There are many environmental consequences induced by the consumption of raw materials, processing operations for the production of building materials, and the disposal of construction wastes. Among construction materials, concrete is of particular interest in relation to a sustainable development, being the most widely used material (Mehta 2002; Damtoft et al. 2008). The extensive worldwide use of concrete, on the one hand, corresponds to a substantial use of resources as well as production of environmental pollution. However, on the other hand, it offers interesting recycling possibilities that can strongly mitigate its overall impact on the environment (Meyer 2009; Jahren 2002). These include, for instance, the use of many types of traditional and innovative mineral additions that show hydraulic or pozzolanic properties (Siddique 2008; Bensted and Barnes 2002; Bertolini et al. 2011) or the use of recycled aggregates (Hendricks and Janssen 2001; Moriconi and Corinaldesi 2008). Improvements of the life-cycle costs of structures and infrastructures may also be obtained by reducing the unfavorable ratio between strength and density that characterizes ordinary concrete or decreasing its thermal conductivity. In this context, the development of lightweight concrete (concrete with dry density lower than $2000 \mathrm{~kg} / \mathrm{m}^{3}$ $\left(124.85 \mathrm{lb} / \mathrm{ft}^{3}\right)$ is attractive for structural applications (EN 206 2013).
Often, structural lightweight concrete is obtained by replacing part of the ordinary aggregate with lightweight aggregate particles (Neville 1995). Although natural materials (such as tuff or pumice) may be used as lightweight aggregates, the transport costs to the place of use and the environmental impact of excavation operation make their use limited to volcanic areas. Undoubtedly, the use of artificial lightweight aggregates may reduce these problems, allowing higher standards for quality control of the product. Expanded clay is the most used and well known among artificial lightweight aggregates currently available. However, the production of this type of aggregate has a significant environmental impact because it involves the excavation of natural clay and requires a thermal transformation process.

Therefore, it becomes interesting to verify the possibility of recycling industrial or civil wastes to obtain alternative lightweight aggregates. Waste glass is an interesting possibility because this material is widely available worldwide, especially in the finer fraction, which cannot be recycled for usual glass applications. Several studies have shown that, after being ground to achieve particle size distributions comparable to those of common cements, waste glass may be used as a mineral addition (Shayan and $\mathrm{Xu}$ 2004; Chen et al. 2002; Naik 2002; Shi and Zheng 2007; Bertolini et al. 2004). A pozzolanic behavior was observed for such an addition and benefits in terms of strength and durability performance of concrete structures have been suggested (Carsana et al. 2014). An alternative use of waste glass in concrete could be in the form of aggregate (Corinaldesi et al. 2005; Ismail and Al-Hashmi 2009; Limbachiya 2009). Nevertheless, the use of bulk waste glass coarse particles is not advisable due to risks of alkali-silica reaction (ASR), being that glass is essentially made of amorphous silica particles (Jin et al. 2000; Meyer 2003; Park and Lee 2004; Shi and Zheng 2007; Kou and Poon 2009; Rajabipour et al. 2010; Yuksel et al. 2013). Recently, processes for the production of expanded glass particles have been developed and the use of expanded glass as a lightweight aggregate for concrete has been proposed by several authors (Meyer 2009; Jahren 2002; Ducman et al. 2002; Nemes and Józsa 2006; Shao et al. 2000, Torres and Garcia-Ruiz 2009; Lam et al. 2007; Mueller et al. 2008; Kralj 2009; Ducman and Mirtic 2009;

ACI Materials Journal, V. 114, No. 2, March-April 2017.

MS No. M-2015-243.R2, doi: 10.14359/51689472, received July 13, 2016, and reviewed under Institute publication policies. Copyright (C) 2017, American Concrete Institute. All rights reserved, including the making of copies unless permission is obtained from the copyright proprietors. Pertinent discussion including author's closure, if any, will be published ten months from this journal's date if the discussion is received within four months of the paper's print publication. 
Table 1-Composition of lightweight concrete mixtures

\begin{tabular}{|c|c|c|c|c|c|c|c|c|}
\hline Mixture & $\begin{array}{l}\text { CEM I } 52.5 \mathrm{R}, \\
\mathrm{kg} / \mathrm{m}^{3}\left(\mathrm{lb} / \mathrm{ft}^{3}\right)\end{array}$ & $\begin{array}{l}\text { Silica fume, } \\
\mathrm{kg} / \mathrm{m}^{3}\left(\mathrm{lb} / \mathrm{ft}^{3}\right)\end{array}$ & $\begin{array}{l}\text { Water, } \mathrm{kg} / \mathrm{m}^{3} \\
\qquad\left(\mathrm{lb} / \mathrm{ft}^{3}\right)\end{array}$ & $\begin{array}{l}\text { Ordinary aggregate, } \\
\mathrm{kg} / \mathrm{m}^{3}\left(\mathrm{lb} / \mathrm{ft}^{3}\right)\end{array}$ & $\begin{array}{l}\text { Expanded glass, } \\
\mathrm{kg} / \mathrm{m}^{3}\left(\mathrm{lb} / \mathrm{ft}^{3}\right)\end{array}$ & $\begin{array}{l}\text { High-range water-reducing } \\
\text { admixture, } \mathrm{kg} / \mathrm{m}^{3}\left(\mathrm{lb} / \mathrm{ft}^{3}\right)\end{array}$ & $w / c$ & $w / b$ \\
\hline A & $474(29.58)$ & $47.4(2.96)$ & $200(12.48)$ & $948(59.16)$ & $95(5.93)$ & $4.41(0.275)$ & 0.42 & 0.38 \\
\hline $\mathrm{C}$ & $420(26.21)$ & $42(2.62)$ & $169(10.55)$ & $977(60.96)$ & $112(6.99)$ & $4.2(0.26)$ & 0.40 & 0.37 \\
\hline
\end{tabular}

Kourti and Cheeseman 2010; Bumanis et al. 2013) and it has also suggested that expansion due to ASR may be negligible because, similarly to other expanded aggregates, the porous structure may prevent the development of internal stresses (ACI Committee 213 2003; Mladenovic et al. 2004). Performance of lightweight concrete with expanded glass could be improved by using silica fume addition, which is known for its filler and pozzolanic effects (Carsana et al. 2014). Nevertheless, for a more widespread use of expanded waste glass aggregate in concrete for long-term stability in wet environments needs to be investigated. This paper describes an experimental study aimed at developing a lightweight concrete with expanded glass particles and silica fume, suitable for structural applications, and evaluating microstructural changes in wet conditions and resistance to the action of aggressive ions.

\section{RESEARCH SIGNIFICANCE}

The use of expanded glass aggregate to produce lightweight concrete would contribute to the improvement of sustainability of the building industry. Recycling of waste glass for the production of aggregate particles is limited by risks of deleterious expansion due to ASR. The use of expanded glass in form of lightweight aggregate particles could prevent such risk and, in the meantime, allows producing, in combination with the use of silica fume, a lightweight structural concrete that can have several positive effects on the environment, such as reducing transportation costs or improving insulation properties of building elements. The first step toward the use of such a material is the demonstration that there are no deleterious interactions between the expanded glass particles and the cement matrix. For this reason, this research investigated, with different tests, the stability of the expanded glass aggregate embedded in the cement matrix and the long-term performance of concrete.

\section{EXPERIMENTAL PROCEDURE}

Tests were carried out using an ordinary river aggregate and a commercial expanded glass aggregate with particles size in the range of 2 to $4 \mathrm{~mm}$ ( 0.079 to $0.157 \mathrm{in}$.). First, aggregate fractions were characterized in terms of particle size distribution, water absorption, and bulk density. The particle density was measured in the saturated surface-dry condition. To test the susceptibility of the aggregates to ASR, expansion tests on $25 \times 25 \times 285 \mathrm{~mm}^{3}(1 \times 1 \times$ 11.2 in. $\left.^{3}\right)$ mortar specimens were carried out, following the procedure described in ASTM C1260. Tests were carried out on a mortar with the fraction passing through a sieve of $4 \mathrm{~mm}(0.157 \mathrm{in}$.) for the ordinary aggregate and a mortar with only the expanded glass particles (size in the range

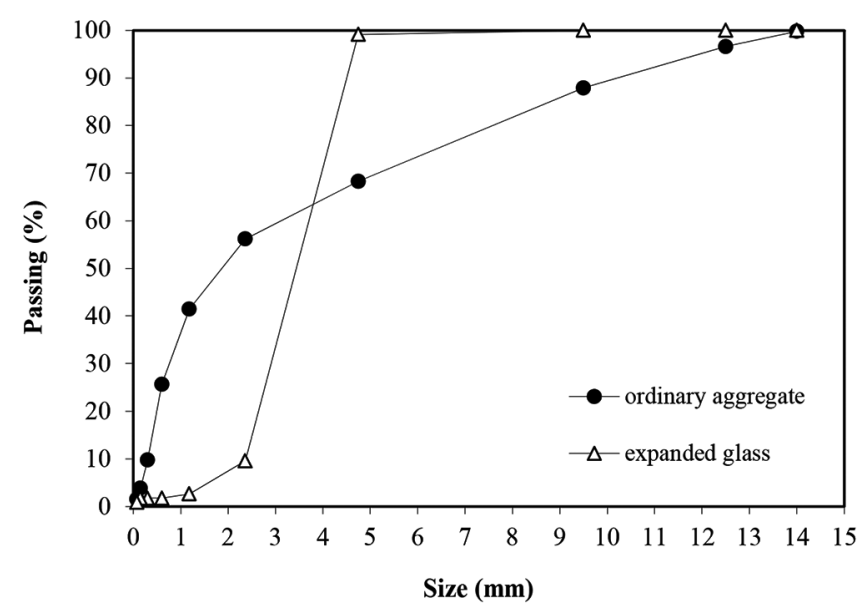

Fig. 1-Particle size distribution of ordinary aggregate and expanded waste glass aggregate.

2 to $4 \mathrm{~mm}$ [0.079 to 0.157 in.] (Fig. 1)). Mortar was mixed with $0.46: 1: 2.25$ water:cement:aggregate ratio by mass for the ordinary sand and $0.46: 1: 0.25$ for the expanded glass, to obtain the same volume proportion of $52 \%$ of aggregate. After 24-hour curing in the mold, specimens were immersed in water at $80^{\circ} \mathrm{C}\left(176^{\circ} \mathrm{F}\right)$ for 24 hours to measure the initial length. They were then immersed in $1 \mathrm{~N} \mathrm{NaOH}$ solution at $80^{\circ} \mathrm{C}\left(176^{\circ} \mathrm{F}\right)$ and linear expansion was measured for 14 days.

To develop a structural lightweight concrete, three mixtures of concrete containing the expanded glass aggregate, indicated respectively by the letters $\mathrm{A}, \mathrm{B}$, and $\mathrm{C}$ (Table 1), were cast. Portland cement (CEM I 52.5R according to EN 197-1 standard) was used and $10 \%$ by mass of silica fume was added. The aggregate was obtained by mixing $70 \%$ by volume of the ordinary aggregate and $30 \%$ by volume of the expanded glass. An acrylic high-range water-reducing admixture (HRWRA) was used. The moisture content at the time of mixing was $0.13 \%$ by mass for the expanded glass aggregate and $4.8 \%$ for the ordinary aggregate. The concretes were characterized in the fresh state (by means of slump test) and in the hardened state (in terms of compressive strength on $100 \mathrm{~mm}$ [3.94 in.] cubes, dynamic elastic modulus, density and electrical resistivity). Dynamic elastic modulus was estimated by measuring the ultrasonic pulse rate in cube specimens, according to RILEM NDT 1 recommendation.

To investigate the long-term stability of the expanded glass aggregate in concrete, cube specimens were immersed in water at 20 and $40^{\circ} \mathrm{C}\left(68\right.$ and $\left.104^{\circ} \mathrm{F}\right)$ for 3,6 , and 9 months, and then subjected to compressive strength tests. Microscopic analyses of the aggregate particles and concrete were carried out with an environmental scanning electron microscope equipped with an EDS system having an ultrathin window detector. 


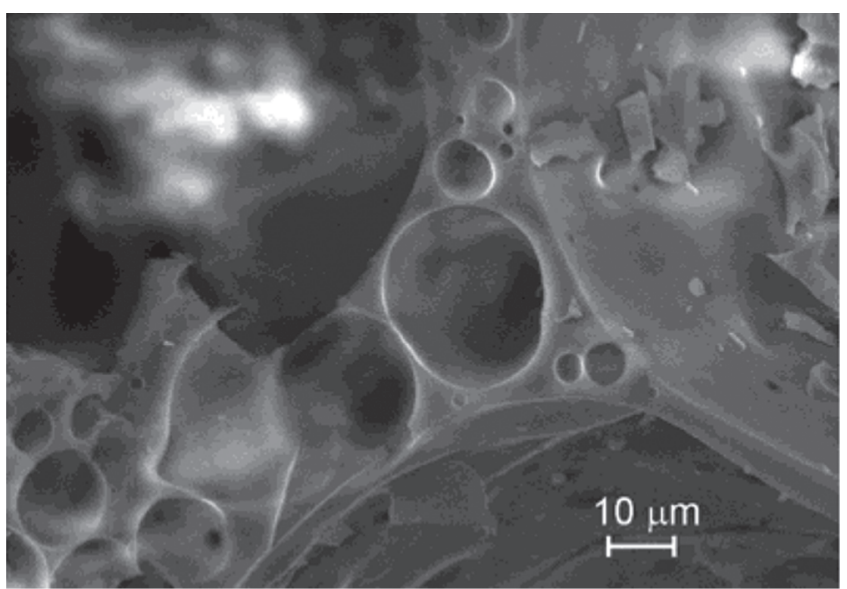

(a)

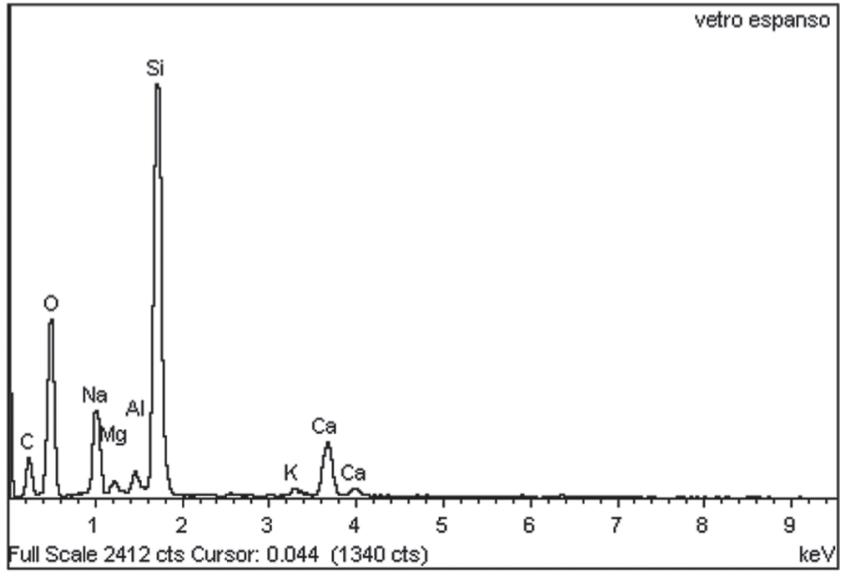

(b)

Fig. 2-(a) Fracture surface of expanded glass particle observed at scanning electron microscope; and (b) EDS analysis.

Durability tests were also carried out on Mixture C. Water absorption was measured on $100 \mathrm{~mm}$ (3.94 in.) cubes by drying at $105^{\circ} \mathrm{C}\left(221^{\circ} \mathrm{F}\right)$ and subsequent immersion in water until a constant weight. Electrical resistivity was measured on $40 \times 40 \times 160 \mathrm{~mm}^{3}\left(1.58 \times 1.58 \times 6.3 \mathrm{in.}^{3}\right)$ prisms cured underwater; the conductance $G$ between copper plates placed on two opposite faces of the specimens was measured with an AC conductivity meter to obtain a uniform current flow through the specimen. The electrical conductivity $\rho$ was then calculated by multiplying the conductance for the ratio between the length of the specimen and the cross section (Carsana et al. 2014). Resistance to sulfate attack was measured following the procedure proposed by ASTM C1012 by measuring the linear expansion of $25 \mathrm{x}$ $25 \times 285 \mathrm{~mm}^{3}\left(1 \times 1 \times 11.2\right.$ in. $\left.^{3}\right)$ prisms immersed in a solution with $50 \mathrm{~g} / \mathrm{L}\left(2.18 \mathrm{lb} / \mathrm{ft}^{3}\right)$ of $\mathrm{Na}_{2} \mathrm{SO}_{4}$ for 6 months. Resistance to the penetration of chlorides was measured on concrete cylinders according to the "inclined cell procedure" of Nordtest NT-BUILD-492, to estimate an apparent diffusion coefficient as described in Carsana et al. (2014). Drying shrinkage was measured on 100 x 100 x $500 \mathrm{~mm}^{3}$ (3.94 x $3.94 \times 19.69$ in. $^{3}$ ) prisms cured for 28 days and then exposed to $20^{\circ} \mathrm{C}\left(68^{\circ} \mathrm{F}\right)$ and $50 \%$ relative humidity $(\mathrm{RH})$ for

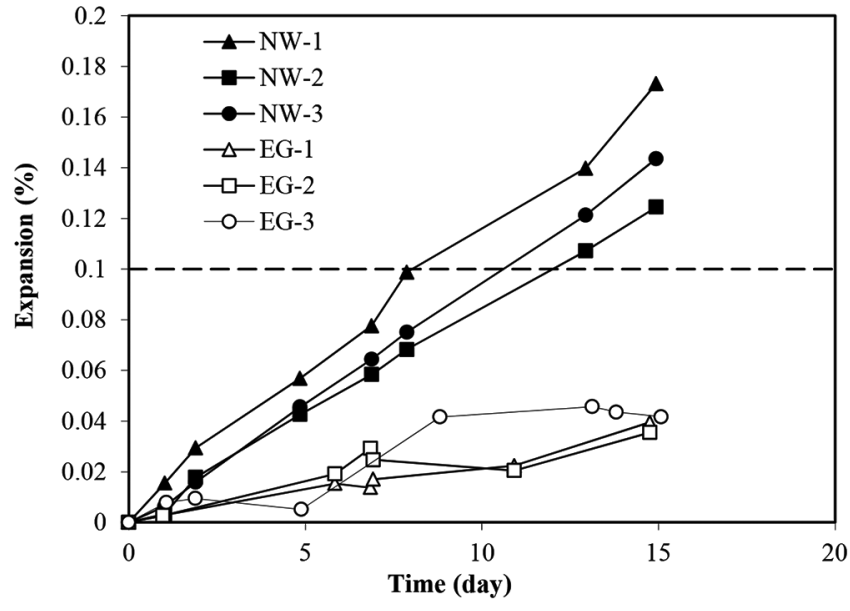

Fig. 3-Expansion in time of mortar specimens with expanded glass (EG) and normalweight aggregate (NW) during ASR tests in $1 \mathrm{~N} \mathrm{NaOH}$ solution at $80^{\circ} \mathrm{C}\left(176^{\circ} \mathrm{C}\right)$; three replicate specimens.

Table 2-Bulk density, water absorption, and moisture content of aggregates

\begin{tabular}{c|c|c|c}
\hline Aggregate & $\begin{array}{c}\text { Bulk density, } \\
\mathrm{kg} / \mathrm{m}^{3}\left(\mathrm{lb} / \mathrm{ft}^{3}\right)\end{array}$ & $\begin{array}{c}\text { Particle density, } \\
\mathrm{kg} / \mathrm{m}^{3}\left(\mathrm{lb} / \mathrm{ft}^{3}\right)\end{array}$ & $\begin{array}{c}\text { Water absorption, } \\
\% \text { mass }\end{array}$ \\
\hline Ordinary & $1780(111)$ & $2660(166)$ & 1 \\
\hline Expanded glass & $183(11.4)$ & $320(20)$ & 25 \\
\hline
\end{tabular}

6 months. All the tests were carried out on two to three replicate specimens.

\section{RESULTS AND DISCUSSION}

Figure 1 shows the particle size distribution of the ordinary and expanded glass aggregates. Density and water absorption of the ordinary and expanded glass aggregates are shown in Table 2. The expanded glass aggregate had an apparent density of $320 \mathrm{~kg} / \mathrm{m}^{3}\left(20 \mathrm{lb} / \mathrm{ft}^{3}\right)$ and water absorption of $25 \%$ by mass (these values fit within the relationship between density and water absorption of different types of expanded glass reported by Nemes and Józsa [2006]). Figure 2(a) describes the fracture surface of a particle of expanded glass observed at the scanning electron microscope showing the porous internal structure, while Fig. 2(b) reports the EDS analysis showing that the expanded aggregate is made of lime-silica glass.

\section{Susceptibility to ASR}

Figure 3 shows the results of ASR tests on mortars; three replicate specimens were tested for each type of aggregate. Mortar made with only the expanded glass aggregate (EG) at the end of the tests showed a negligible expansion of approximately $0.04 \%$, which was lower than the threshold of 0.08 to $0.1 \%$ proposed as safe value in relation to the use of the aggregates in the concrete (Shayan and Morris 2001; Thomas et al. 2007). The expansion was even higher for the mortar with the normalweight sand (NW). The low expansion of lightweight concrete with expanded glass particles is in agreement with results reported by Mladenovic et al. (2004) and confirms quite a different behavior from concrete 


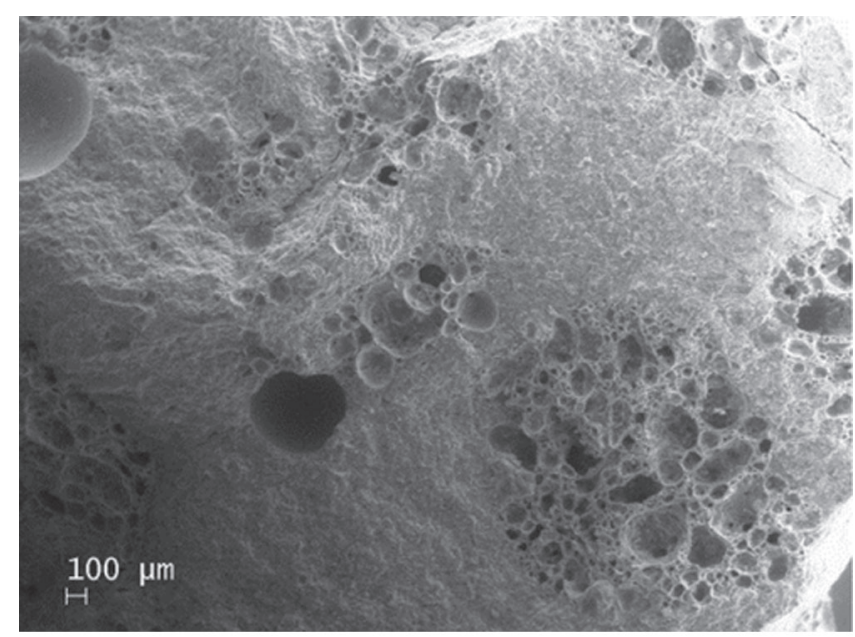

(a)

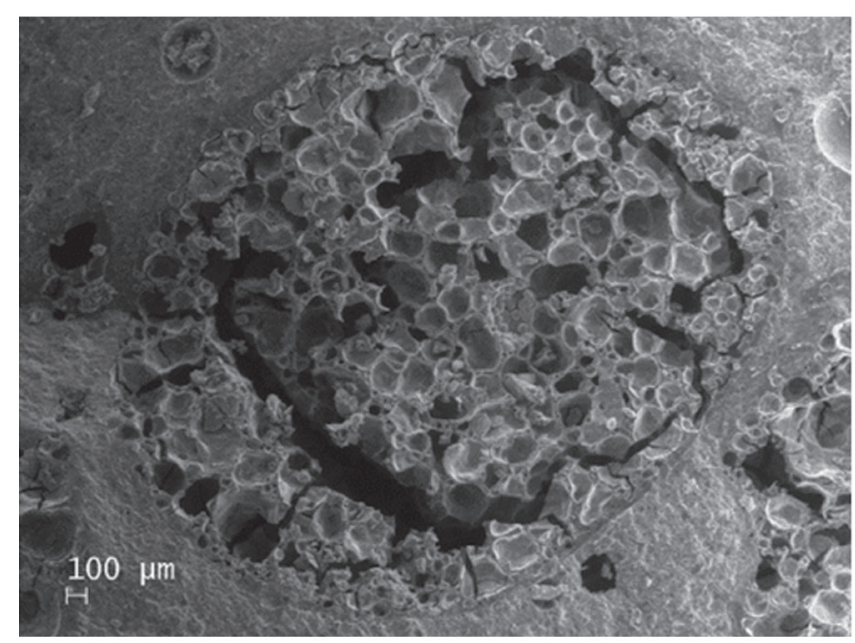

(b)

Fig. 4-SEM images of expanded glass aggregated in mortar samples: (a) at end of curing; and (b) after ASR tests in $1 \mathrm{~N}$ $\mathrm{NaOH}$ solution at $80^{\circ} \mathrm{C}\left(176^{\circ} \mathrm{C}\right)$.

with non-expanded glass particles as shown, for instance, by Jin et al. (2000) with tests similar to those carried out in this work. Although expansion of concrete was negligible during ASR tests on mortar specimens with expanded glass aggregates and no deterioration or cracking was detected on the surface of the specimens, the observation with the scanning electron microscope of aggregates embedded in the cement matrix showed the presence of internal fractures after the ASR tests (Fig. 4). This result shows that a reaction occurred between glass particles and the alkaline solution at high temperature. Nevertheless, this reaction was limited to the inner part of expanded glass particles, while the interface between the cement matrix and aggregate was observed to be intact. These results confirm that the expanded glass particles are not immune from alkalis attack, as already shown by other authors (Ducman et al. 2002; Mladenovic et al. 2004; Bumanis et al. 2013).
Table 3-Properties of fresh concrete and wet density on cubes

\begin{tabular}{c|c|c|c}
\hline Mixture & $\begin{array}{c}\text { Slump, mm } \\
\text { (in.) }\end{array}$ & $\begin{array}{c}\text { Entrapped air, } \% \\
\text { volume }\end{array}$ & Wet density, $\mathrm{kg} / \mathrm{m}^{3}\left(\mathrm{lb} / \mathrm{ft}^{3}\right)$ \\
\hline A & $>250(>10)$ & 5.7 & 1250 to $2138(78$ to 133$)$ \\
\hline B & $220(8.7)$ & 5.7 & 1888 to $1950(118$ to 122$)$ \\
\hline C & $170(6.7)$ & 7.1 & 1700 to $1780(106$ to 111$)$ \\
\hline
\end{tabular}

\section{Lightweight concrete}

Table 3 summarizes the properties in the fresh state of the three concrete mixtures. The first concrete (A) had water content of $200 \mathrm{~kg} / \mathrm{m}^{3}\left(12.48 \mathrm{lb} / \mathrm{ft}^{3}\right)$, a water-cement ratio $(w / c)$ of 0.42 , and water-binder ratio $(w / b)$ of 0.38 (Table 1$)$. In spite of the high binder dosage and the presence of silica fume, this concrete showed an excessive fluidity, with a slump exceeding $250 \mathrm{~mm}$ (10 in.), and lack of cohesion of the lightweight aggregate with cement paste. The mixture then experienced segregation during mixing; observation of hardened cube specimens showed great variability in the distribution of lightweight particles, which was clearly visible to the naked eye on the fracture surface of concrete. Consequently, the density measured on the hardened cubes was extremely variable, from values of $1250 \mathrm{~kg} / \mathrm{m}^{3}\left(78 \mathrm{lb} / \mathrm{ft}^{3}\right)$ in specimens that embedded the highest amount of expanded glass particles to values higher than $2100 \mathrm{~kg} / \mathrm{m}^{3}\left(131 \mathrm{lb} / \mathrm{ft}^{3}\right)$ in the specimens with the lowest amount (Table 3 ).

To improve the cohesion of the mixture, the dosage of water was reduced by approximately $10 \%$ in Concrete B and the binder dosage was adjusted to reach a $w / b$ of 0.36 (Table 1 ). This allowed obtaining a cohesive lightweight concrete with a density of 1950 to $1990 \mathrm{~kg} / \mathrm{m}^{3}$ (122 to $\left.124 \mathrm{lb} / \mathrm{ft}^{3}\right)$ and slump of $220 \mathrm{~mm}(8.7 \mathrm{in}$.) - that is, a class of consistence S5 according to EN 206. A further reduction in the water and binder contents and an increase in the lightweight aggregate content in Concrete $\mathrm{C}$ (Table 1) allowed a decrease in the density to 1700 to $1780 \mathrm{~kg} / \mathrm{m}^{3}$ (106 to $111 \mathrm{lb} / \mathrm{ft}^{3}$ ) while maintaining a slump of $170 \mathrm{~mm}$ (6.7 in.) — a consistence class S4 (Table 3).

Figure 5 shows the results of compressive strength and dynamic elastic modulus tests carried out at different curing times on the three concrete mixtures. Mechanical tests confirmed the lack of homogeneity of Concrete A, which showed compressive strength values ranging between 9.7 and $41.6 \mathrm{MPa}$ (1.4 and $6 \mathrm{ksi}$ ) after 7 days of curing. More reproducible values were measured for Concretes $\mathrm{B}$ and $\mathrm{C}$. Values measured after 28 days of curing were only slightly higher than those measured after 7 days, showing the contribution of silica fume, already at early ages. Specimens of Concrete $\mathrm{C}$ had values of compressive strength and dynamic elastic modulus slightly lower than those found at the same curing for Concrete $\mathrm{B}$, due to the higher $w / b$. Nevertheless, the compressive strength at curing times of 28 days of Concrete $\mathrm{C}$ reached 23 to $29 \mathrm{MPa}$ (3.3 to $4.2 \mathrm{ksi}$ ) and the dynamic elastic modulus was higher than $17 \mathrm{GPa}$ (2466 ksi). The strength values obtained with Concrete $\mathrm{C}$ fit the correlation between strength and density of concretes with different types of expanded glass particles reported by Nemes and Józsa (2006). 


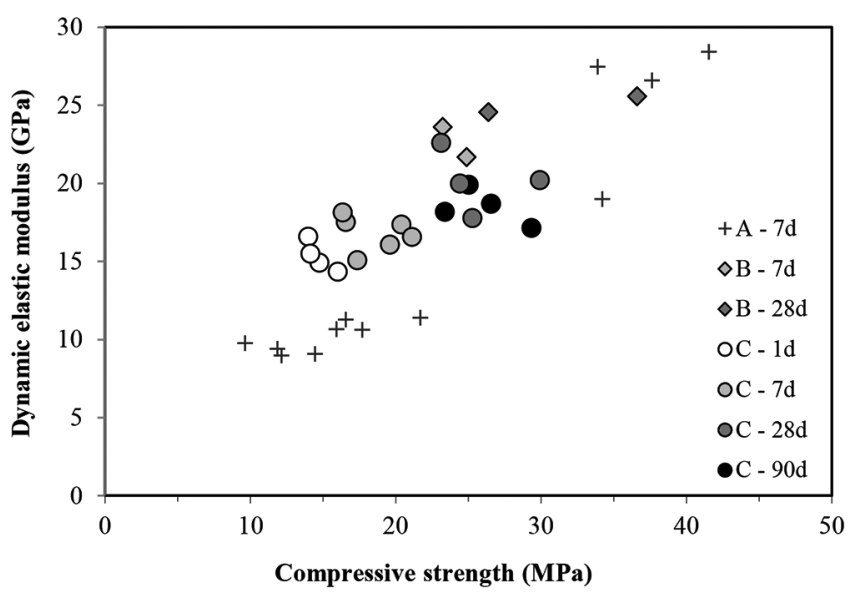

Fig. 5-Relationship between compressive strength and dynamic elastic modulus of Concretes $A, B$, and $C$, measured at different curing times.

\section{Environmental actions}

To evaluate possible alteration in time of the mechanical properties of the lightweight concrete in wet environment, due to the susceptibility of the expanded glass aggregate to the alkalinity of the concrete, compressive tests were carried out on specimens of Concrete $\mathrm{C}$ after different times of immersion in water. Figure 6 shows that the strength after up to 9 months of immersion are comparable to those measured after 28 days of curing (Fig. 5). Indeed, although a slight decrease in time of compressive strength may appear in Fig. 6 for tests at $20^{\circ} \mathrm{C}\left(68^{\circ} \mathrm{F}\right)$, the lowest results at 9 months are similar to those obtained after 28 days of moist curing. Furthermore, no decrease was observed for samples immersed at the higher temperature of $40^{\circ} \mathrm{C}\left(104^{\circ} \mathrm{F}\right)$ that could favor alkali-aggregate reactions from 3 to 9 months. Overall, these results do not show any clear evidence of loss of strength. Nonetheless, observations at the scanning electron microscope detected some degradation of the particles of expanded glass in concrete (Fig. 7), showing that the inner part of expanded glass particles was attacked by the alkalis produced by the hydration of cement under severe conditions of permanent water immersion. The absence of cracks in the cement matrix and the results in terms of compressive strength indicate, however, that the expansive effects produced by alkali-aggregate reaction are mitigated by the porous structure of the aggregate without inducing stresses in the hardened cement matrix. It was also observed that the interface between cement paste and the surface of the aggregate was not attacked, and this might be attributed to a beneficial effect of silica fume, according to other authors that have suggested a positive influence of pozzolanic additions (Lam et al. 2007; Bumanis et al. 2013). These results suggest that Concrete $\mathrm{C}$ may be suitable for applications where a structural and lightweight concrete is required, although further tests are advisable to better investigate the effect of alkalis on the long-term performance of concrete under real environmental exposure conditions.

Besides the stability in wet conditions, durability of Concrete I is also related to its resistance to the penetration of aggressive ions. Further results of tests aimed at studying the resistance of the lightweight Concrete $\mathrm{C}$ to aggressive agents

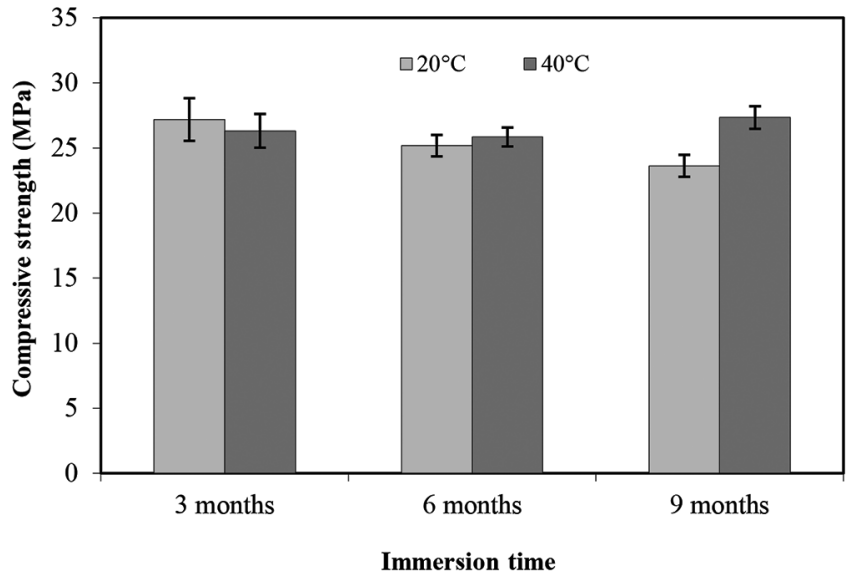

Fig. 6-Compressive strength of Concrete $C$ after 3, 6, and 9 months of immersion in water at 20 and $40^{\circ} \mathrm{C}$ (68 and $\left.104^{\circ} \mathrm{F}\right)$; two replicate specimens.

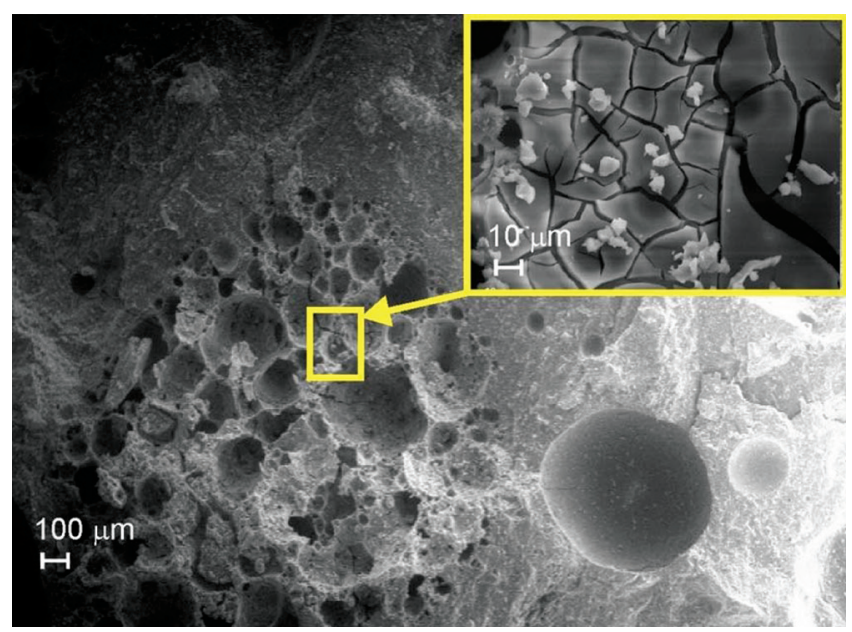

Fig. 7-SEM image of fracture surface of Concrete $C$ after 3 months of immersion in water.

of concrete are summarized in Table 4 . The high porosity due to the presence of the expanded glass aggregate led to water absorption values of the lightweight concrete higher than $11 \%$ by mass. Nevertheless, it should be considered that the resistance to the penetration of aggressive species is mainly related to the capillary porosity of the hardened cement paste, which was estimated through the evolution in time of the electrical resistivity of the concrete. Figure 8 shows the electrical resistivity measured on specimens immersed in water that reached values above $150 \Omega \cdot \mathrm{m}$ after 6 months of curing, suggesting the presence of a dense microstructure able to provide high resistance to the ingress of aggressive agents, which may be attributed both to the low $w / b$ and the presence of silica fume (Bertolini et al. 2013; Carsana et al. 2014). In agreement with results previously obtained on concrete with expanded clay and high volumes of fly ash (Bertolini et al. 2003), it may be assumed that the high porosity of the expanded glass particles (possibly even if it further increases in time due to alkalis damage) may have a negligible effect on the transport properties of the lightweight concrete, whose permeability is essentially governed by the hydrated cement matrix. 
Table 4-Results of durability tests on lightweight Concrete C

\begin{tabular}{|c|c|c|c|}
\hline Property & Specimens & Testing conditions & Results \\
\hline Water absorption & $100 \mathrm{~mm}(3.94$ in.) cubes & Drying + immersion in water & 11.2 to $11.6 \%$ by mass \\
\hline Electrical resistivity & $\begin{array}{c}40 \times 40 \times 160 \mathrm{~mm}^{3} \\
\left(1.57 \times 1.57 \times 6.3 \mathrm{in}^{3}\right) \text { prisms }\end{array}$ & Immersion in water, 180 days & 155 to $165 \Omega \cdot \mathrm{m}$ \\
\hline Sulfate expansion & $\begin{array}{c}25 \times 25 \times 285 \mathrm{~mm}^{3} \\
\left(1 \times 1 \times 11.2 \mathrm{in.}^{3}\right) \text { prisms }\end{array}$ & $50 \mathrm{~g} / \mathrm{L} \mathrm{Na}_{2} \mathrm{SO}_{4}, 180$ days & 0.039 to $0.040 \%$ \\
\hline Chloride diffusion coefficient & $100 \mathrm{~mm}$ (3.94 in.) diameter cylinders & NT-BUILD-492 & 4.98 to $5.33 \times 10^{-12} \mathrm{~m}^{2} / \mathrm{s}\left(5.4\right.$ to $\left.5.7 \times 10^{-11} \mathrm{ft}^{2} / \mathrm{s}\right)$ \\
\hline Shrinkage & $\begin{array}{c}100 \times 100 \times 500 \mathrm{~mm}^{3} \\
\left(3.94 \times 3.94 \times 19.69 \text { in. }^{3}\right) \text { prisms }\end{array}$ & $50 \% \mathrm{RH}, 20^{\circ} \mathrm{C}\left(68^{\circ} \mathrm{F}\right), 180$ days & 620 to $640 \mu \mathrm{m} / \mathrm{m}$ \\
\hline
\end{tabular}

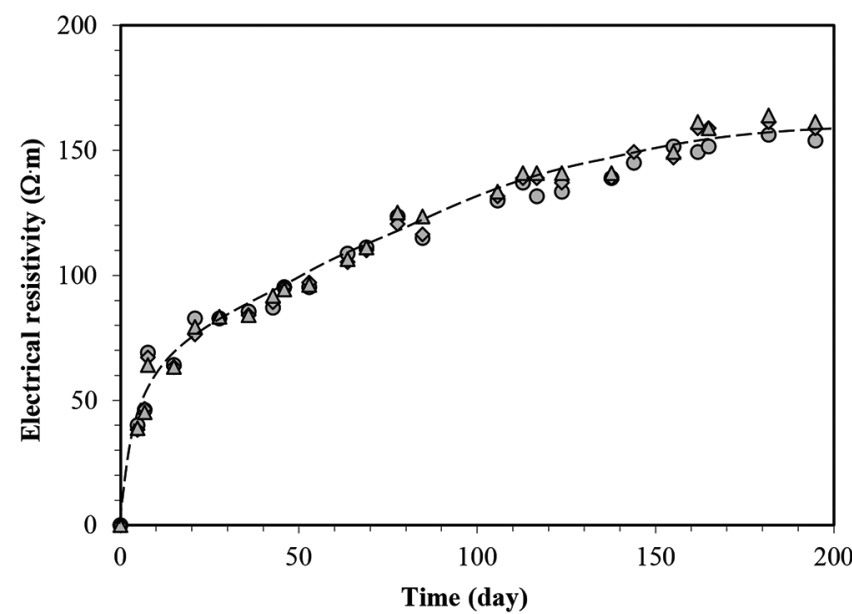

Fig. 8-Evolution in time of electrical resistivity of specimens of Concrete $C$ cured under water (different symbols refer to three replicate specimens).

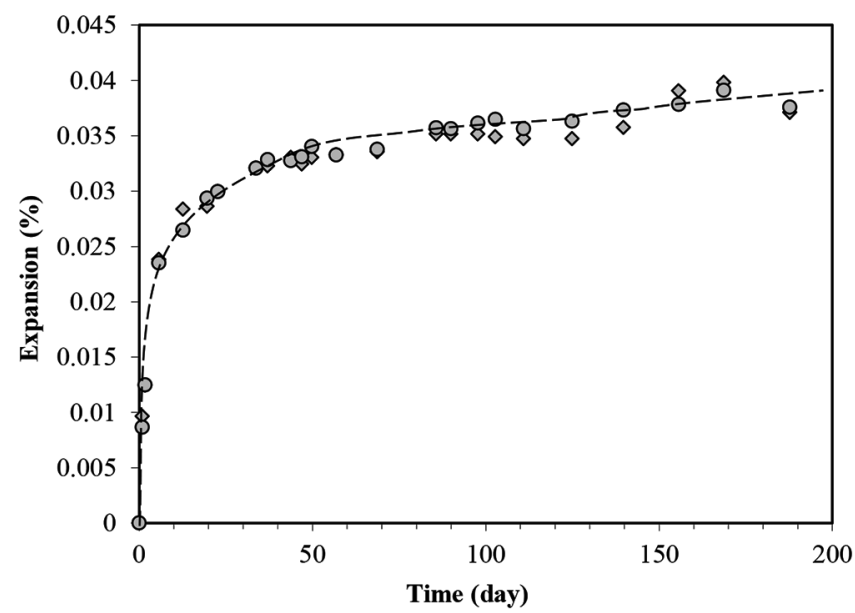

Fig. 9-Expansion of specimens of Concrete C immersed in $50 \mathrm{~g} / \mathrm{L}\left(2.18 \mathrm{lb} / \mathrm{ft}^{3}\right) \mathrm{Na}_{2} \mathrm{SO}_{4}$ solution (different symbols refer to two replicate specimens).

This result was confirmed by tests aimed at studying the resistance to the penetration of aggressive ions. Figure 9 shows the linear expansion of specimens of Concrete $\mathrm{C}$ immersed in a solution with $50 \mathrm{~g} / \mathrm{L}\left(2.18 \mathrm{lb} / \mathrm{ft}^{3}\right)$ of $\mathrm{Na}_{2} \mathrm{SO}_{4}$. Expansion of specimens immersed in the aggressive sulfate solution was indeed negligible even after 6 months of exposure, showing good resistance of the concrete to this type of attack. Concrete $\mathrm{C}$ also showed to be highly resistant to the penetration of chlorides; the diffusion coefficient evaluated with the inclined

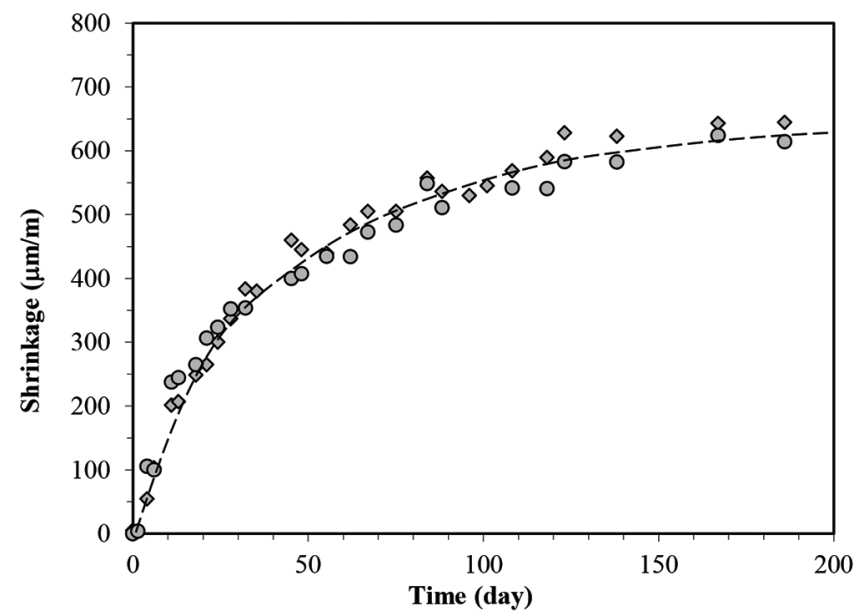

Fig. 10-Drying shrinkage of Concrete C exposed to 50\% $\mathrm{RH}$ and $20^{\circ} \mathrm{C}\left(68^{\circ} \mathrm{F}\right)$ (different symbols refer to two replicate specimens).

cell test was of $5 \times 10^{-12} \mathrm{~m}^{2} / \mathrm{s}\left(5.38 \times 10^{-11} \mathrm{ft}^{2} / \mathrm{s}\right)$ (Table 4), comparable to that of normalweight concrete commonly used for aggressive environments (Bertolini et al. 2010).

In spite of the high dosage of binder and the presence of the lightweight aggregate, the concrete also showed a reasonably low drying shrinkage; after 6 months of exposure at $50 \% \mathrm{RH}$, it was approximately $600 \mu \mathrm{m} / \mathrm{m}$ ( $\mu$ in./in.), as shown in Fig. 10 .

\section{SUMMARY AND CONCLUSIONS}

The results described in this work showed the possibility of using expanded glass aggregates to obtain a structural lightweight concrete with a density lower than $1800 \mathrm{~kg} / \mathrm{m}^{3}$ $\left(112 \mathrm{lb} / \mathrm{ft}^{3}\right)$ and compressive strength on the order of $25 \mathrm{MPa}$ (3.6 ksi). Electron scanning microscope observation of the expanded glass particles embedded in the cement matrix after immersion in highly alkaline solution and water showed the alteration of the microstructure of expanded glass particles, confirming their susceptibility to alkali-silica reaction (ASR). However, the absence of cracks in the cement matrix and the good strength performance of specimens immersed in water, even at a temperature of $40^{\circ} \mathrm{C}\left(104^{\circ} \mathrm{F}\right)$, suggest that no deleterious expansive effects produced by the reaction should be expected in the lightweight concrete with the expanded glass aggregate.

The low $w / b$ and the presence of silica fume addition, besides helping in improving the cohesion of the fresh concrete, showed to be beneficial for the resistance to the penetration of aggressive sulfate and chloride ions. 


\section{AUTHOR BIOS}

Maddalena Carsana is an Assistant Professor of construction materials of the Faculty of Civil Engineering at the Polytechnic University of Milan, Milan, Italy. She received her PhD in materials engineering. Her research interests include durability and conservations of reinforced concrete structures, and the development of new cementitious materials based on recycled materials and mineral additions with possible pozzolanic activity.

ACI member Luca Bertolini is a Full Professor of construction materials and durability of materials at Polytechnic University of Milan. His research interests include corrosion of steel in concrete and its prevention.

\section{ACKNOWLEDGMENTS}

This research was financed by GrasCalce S.p.A. The authors are grateful to S. Grimaldi for his contribution to the setup of the experimental program.

\section{REFERENCES}

ACI Committee 213, 2003, "Guide for Structural Lightweight-Aggregate Concrete (ACI 213R-03)," American Concrete Institute, Farmington Hills, MI, 38 pp.

Bensted, J., and Barnes, P., 2002, Structure and Performance of Cements, second edition, Spon Press, London, England, 584 pp.

Bertolini, L.; Carsana, M.; and Gastaldi, M., 2003, "Properties of a Self-Compacting Mortar with Lightweight Aggregate," System-Based Vision for Strategic and Creative Design, F. Bontempi, ed., Balkema Publishers, pp. 1929-1935.

Bertolini, L.; Carsana, M.; Cassago, D.; Quadrio Curzio, A.; and Collepardi, M., 2004, "MSWI Ashes as Mineral Additions in Concrete," Cement and Concrete Research, V. 34, No. 10, pp. 1899-1906. doi: 10.1016/j.cemconres.2004.02.001

Bertolini, L.; Lollini, F.; and Redaelli, E., 2010, "Comparison of Resistance to Chloride Penetration of Different Types of Concrete through Migration and Ponding Tests," Modelling of Corroding Concrete Structures, C. Andrade and G. Mancini, eds., RILEM Publications, Springer, pp. 125-135.

Bertolini, L.; Carsana, M.; Frassoni, M.; and Gelli, M., 2011, "Pozzolanic Additions for Durability of Concrete Structures," Proceedings of the Institution of Civil Engineers-Construction Materials, V. 164, No. 6, pp. 283-291. doi: 10.1680/coma.1000041

Bertolini, L.; Elsener, B.; Pedeferri, P.; Redaelli, E.; and Polder, R., 2013, Corrosion of Steel in Concrete-Prevention, Diagnosis, Repair, second edition, Wiley-VCH, Wienheim, Germany.

Bumanis, G.; Bajare, D.; Locs, J.; and Korjakins, A., 2013, “Alkali-Silica Reactivity of Foam Glass Granules in Structure of Lightweight Concrete," Construction and Building Materials, V. 47, pp. 274-281. doi: 10.1016/j. conbuildmat.2013.05.049

Carsana, M.; Frassoni, M.; and Bertolini, L., 2014, "Comparison of Ground Waste Glass with Other Supplementary Cementitious Materials," Cement and Concrete Composites, V. 45, pp. 39-45. doi: 10.1016/j. cemconcomp.2013.09.005

Chen, G.; Lee, H.; Young, K. L.; Yue, P. L.; Wong, A.; Tao, T.; and Choi, K. K., 2002, "Glass Recycling in Cement Production-An Innovative Approach," Cement and Concrete Research, V. 22, No. 7, pp. 747-753.

Corinaldesi, V.; Gnappi, G.; Moriconi, G.; and Montenero, A., 2005, "Reuse of Ground Waste Glass as Aggregate for Mortars," Waste Management (New York, N.Y.), V. 25, No. 2, pp. 197-201. doi: 10.1016/j.wasman.2004.12.009

Damtoft, J. S.; Lukasik, J.; Herfort, D.; Sorrentino, D.; and Gartner, E. M., 2008, "Sustainable Development and Climate Change Initiatives," Cement and Concrete Research, V. 38, No. 2, pp. 115-127. doi: 10.1016/j. cemconres.2007.09.008

Ducman, V.; Mladenovic, A.; and Suput, J. S., 2002, "Lightweight Aggregate Based on Waste Glass and its Alkali-silica Reactivity," Cement and Concrete Research, V. 32, No. 2, pp. 223-226. doi: 10.1016/ S0008-8846(01)00663-9

Ducman, V., and Mirtic, B., 2009, "The Applicability of Different Waste Materials for the Production of Lightweight Aggregates," Waste Management (New York, N.Y.), V. 29, No. 8, pp. 2361-2368. doi: 10.1016/j. wasman.2009.02.013

EN 206, 2013, "Concrete-Specification, Performance, Production and Conformity," European Committee for Standardization, Brussels, Belgium.

Hendricks, C. F., and Janssen, G. M. T., 2001, "Construction and Demolition Waste: General Process Aspects," Heron, V. 46, No. 2, pp. 79-88.

Ismail, Z. Z., and Al-Hashmi, E. A., 2009, "Recycling of Waste Glass as a Partial Replacement for Fine Aggregate in Concrete," Waste Management (New York, N.Y.), V. 29, No. 2, pp. 655-659. doi: 10.1016/j. wasman.2008.08.012

Jahren, P., 2002, "Do Not Forget the Other Chapters," Concrete International, V. 24, No. 7, July, pp. 41-44.
Jin, W.; Meyer, C.; and Baxter, S., 2000, “'Glascrete'-Concrete with Glass Aggregate," ACI Materials Journal, V. 97, No. 2, Mar.-Apr., pp. 208-213.

Kou, S. C., and Poon, C. S., 2009, "Properties of Self-Compacting Concrete Prepared with Recycled Glass Aggregate," Cement and Concrete Composites, V. 31, No. 2, pp. 107-113. doi: 10.1016/j.cemconcomp.2008.12.002

Kourti, I., and Cheeseman, C. R., 2010, "Properties and Microstructure of Lightweight Aggregate Produced from Lignite Coal Fly Ash and Recycled Glass," Resources, Conservation and Recycling, V. 54, No. 11, pp. 769-775. doi: 10.1016/j.resconrec.2009.12.006

Kralj, D., 2009, "Experimental Study of Recycling Lightweight Concrete with Aggregates Containing Expanded Glass," Process Safety and Environmental Protection, V. 87, No. 4, pp. 267-273. doi: 10.1016/j. psep.2009.03.003

Lam, C. S.; Poon, C. S.; and Chan, D., 2007, "Enhancing the Performance of Pre-cast Concrete Blocks by Incorporating Waste Glass-ASR Consideration," Cement and Concrete Composites, V. 29, No. 8, pp. 616-625. doi: 10.1016/j.cemconcomp.2007.03.008

Limbachiya, M. C., 2009, "Bulk Engineering and Durability Properties of Washed Glass Sand Concrete," Construction and Building Materials, V. 23, No. 2, pp. 1078-1083. doi: 10.1016/j.conbuildmat.2008.05.022

Mehta, P. K., 2002, "Greening of the Concrete Industry for Sustainable Development," Concrete International, V. 24, No. 7, July, pp. 23-29.

Meyer, C., 2003, "Glass Concrete-Putting Sustainability to Work in a Decorative Way," Concrete International, V. 25, No. 6, June, pp. 55-68.

Meyer, C., 2009, "The Greening of the Concrete Industry," Cement and Concrete Composites, V. 31, No. 8, pp. 601-605. doi: 10.1016/j. cemconcomp.2008.12.010

Mladenovic, A.; Suput, J. S.; Ducman, V.; and Skapin, A. S., 2004, "Alkali-Silica Reactivity of Some Frequently Used Lightweight Aggregate," Cement and Concrete Research, V. 34, No. 10, pp. 1809-1816. doi: 10.1016/j.cemconres.2004.01.017

Moriconi, G., and Corinaldesi, V., 2008, "Influence of Mineral Additions on the Performance of 100\% Recycled Aggregate Concrete," Construction and Building Materials, V. 23, No. 8, pp. 2869-2876.

Mueller, A.; Sokolova, S. N.; and Vereshagin, V. I., 2008, "Characteristics of Lightweight Aggregates from Primary and Recycled Raw Materials," Construction and Building Materials, V. 22, No. 4, pp. 703-712. doi: 10.1016/j.conbuildmat.2007.06.009

Naik, T., 2002, "Greener Concrete Using Recycled Materials," Concrete International, V. 24, No. 7, July, pp. 45-49.

Nemes, R., and Józsa, Z., 2006, "Strength of Lightweight Glass Aggregate Concrete," Journal of Materials in Civil Engineering, ASCE, V. 18, No. 5, pp. 710-714. doi: 10.1061/(ASCE)0899-1561(2006)18:5(710)

Neville, A. M., 1995, Properties of Concrete, Longman Scientific \& Technical, Harlow, UK.

Park, S., and Lee, B., 2004, "Studies on Expansion Properties in Mortar Containing Waste Glass and Fibers," Cement and Concrete Research, V. 34, No. 7, pp. 1145-1152. doi: 10.1016/j.cemconres.2003.12.005

Rajabipour, F.; Maraghechi, H.; and Fischer, G., 2010, "Investigating the Alkali-Silica Reaction of Recycled Glass Aggregates in Concrete Materials," Journal of Materials in Civil Engineering, ASCE, V. 22, No. 12, pp. 1201-1208. doi: 10.1061/(ASCE)MT.1943-5533.0000126

Siddique, R., 2008, Waste Materials and By-Products in Concrete, Springer-Verlag, Berlin, Germany.

Shao, Y.; Lefort, T.; Moras, S.; and Rodriguez, D., 2000, "Studies on Concrete Containing Ground Waste Glass," Cement and Concrete Research, V. 30, No. 1, pp. 91-100. doi: 10.1016/S0008-8846(99)00213-6

Shayan, A., and Morris, H., 2001, "A Comparison of RTA T363 and ASTM C1260 Accelerated Mortar Bar Test Methods for Detecting Reactive Aggregates," Cement and Concrete Research, V. 31, No. 4, pp. 655-663. doi: 10.1016/S0008-8846(00)00491-9

Shayan, A., and Xu, A., 2004, "Value-Added Utilisation of Waste Glass in Concrete," Cement and Concrete Research, V. 34, No. 1, pp. 81-89. doi: 10.1016/S0008-8846(03)00251-5

Shi, C., and Zheng, K., 2007, "A Review on the Use of Waste Glasses in the Production of Cement and Concrete," Resources, Conservation and Recycling, V. 52, No. 2, pp. 234-247. doi: 10.1016/j.resconrec.2007.01.013

Thomas, M.D.A.; Fournier, B.; Folliard, K. J.; Shehata, M. H.; Ideker, J. H.; and Rogers, C., 2007, "Performance Limits for Evaluating Supplementary Cementing Materials using Accelerated Mortar Bar Test," ACI Materials Journal, V. 104, No. 2, Mar.-Apr., pp. 115-122.

Torres, M. L., and Garcia-Ruiz, P. A., 2009, "Lightweight Pozzolanic Materials Use in Mortars: Evaluation of their Influence on Density, Mechanical Strength and Water Absorption," Cement and Concrete Composites, V. 31, No. 2, pp. 114-119. doi: 10.1016/j.cemconcomp.2008.11.003

Yuksel, C.; Ahari, R. S.; Ahari, B. A.; and Ramyar, K., 2013, "Evaluation of Three Test Methods for Determining the Alkali-Silica Reactivity of Glass Aggregate," Cement and Concrete Composites, V. 38, pp. 57-64. doi: 10.1016/j.cemconcomp.2013.03.002 

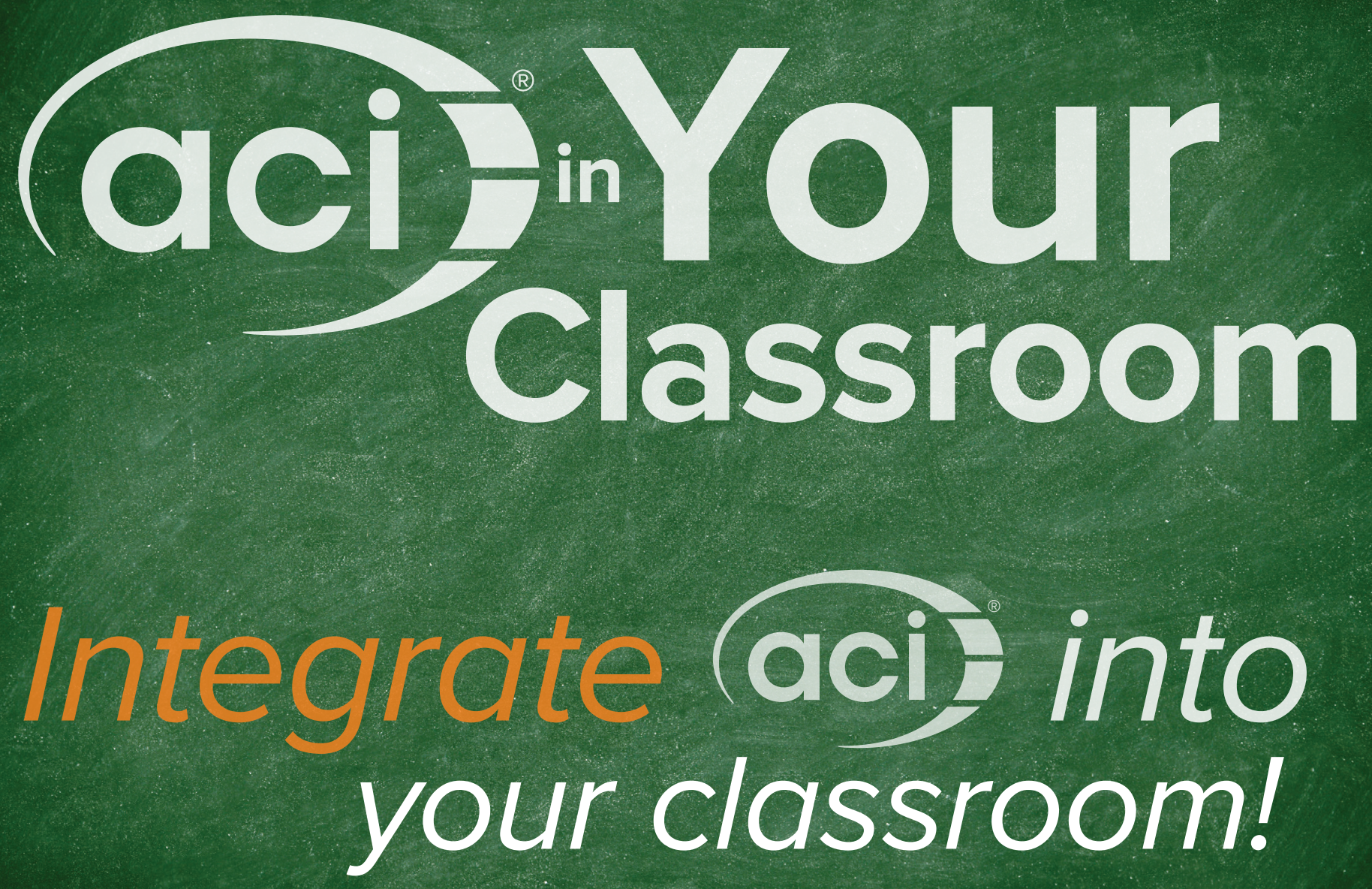

To support future leaders, ACl has launched several initiatives to engage students in the Institute's activities and programs - select programs that may be of interest to Educators are:

- Free student membership - encourage students to sign up

- Special student discounts on ACI 318 Building Code Requirements for Structural Concrete, ACI 530 Building Code Requirements and Specification for Masonry Structure, \& Formwork for Concrete manual.

- Access to Concrete International - free to all $\mathrm{ACl}$ student members

- Access to ACI Structural Journal and ACI Materials Journal - free to all $\mathrm{ACl}$ student members

- Free sustainability resources - free copies of Sustainable Concrete Guides provided to universities for use in the classroom

- Student competitions - participate in ACl's written and/or team-based competitions
- Scholarships and fellowships - students who win awards are provided up to $\$ 10,000$ and may be offered internships and paid travel to attend ACl's conventions

- ACl Award for University Student Activities receive local and international recognition for your University's participation in concrete related activities

- Free access to ACI Manual of Concrete Practice - in conjunction with ACl's chapters, students are provided free access to the online $\mathrm{ACl}$ Manual of Concrete Practice

- $\mathrm{ACl}$ online recorded web sessions and continuing education programs - online learning tools ideal for use as quizzes or in-class study material 